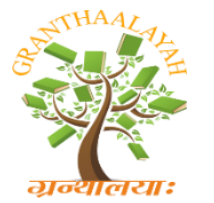

$$
\begin{gathered}
\text { INTERNATIONAL JOURNAL OF RESEARCH - } \\
\text { GRANTHAALAYAH } \\
\text { A knowledge Repository }
\end{gathered}
$$

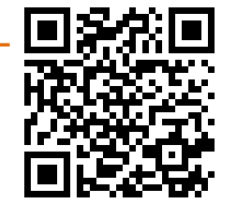

Management

\title{
IMPACT OF THE UNITED STATES AND CHINA TRADE WAR ON GROWTH IN ASEAN COUNTRIES
}

\author{
Kamran Jafarpour Ghaleh Teimouri ${ }^{* 1}$, Seyed Mohammad Taghi Raeissadat ${ }^{2}$ \\ ${ }^{*}{ }_{1,2}$ Faculty of Geographical Science, Kharazmi University of Tehran, Iran
}

\begin{abstract}
For more than a century, American had the biggest economy and the highest Gross Domestic Product (GDP) about 24.1\%. On the other side of the world. Recently, China with 15.1\% Gross Domestic Product (GDP) placed as the second biggest and the most influential economy in the world in 2017 (World Bank, 2019). Therefore, China and United States together have over 40\% of the world GDP with the huge spatial economic influence in the world. The impact of a trade war between the United States and China has a negative influence in other countries and regions in particular in the ASEAN countries. The ASEAN countries are very exposed to China and United States they are more vulnerable to trade war between the United States and China. This study first evaluates the degree of negative impact of China and United States trade war on ASEAN countries. After that, show how an effective regional economic integration can minimize such problems in future. This research is based on available secondary data in United States government reports (e.g., United States Department of State, Office of United States trade) and (e.g. OCBC Bank and ASEAN). Based on data and research the descriptive-analytical method is used in this paper.
\end{abstract}

Keywords: Trade War; China; United States; ASEAN; Regional Integration.

Cite This Article: Kamran Jafarpour Ghaleh Teimouri, and Seyed Mohammad Taghi Raeissadat. (2019). "IMPACT OF THE UNITED STATES AND CHINA TRADE WAR ON GROWTH IN ASEAN COUNTRIES." International Journal of Research - Granthaalayah, 7(3), 64-78. https://doi.org/10.29121/granthaalayah.v7.i3.2019.944.

\section{Introduction}

Trade war is known as protectionism and in fact is an action that government takes by tax or tariff. The recent trade war is between the United States and China "US-China" trade war. There are some differences between this trade war and the other trade wars in the world. First, the United States and China together have over 30\% of the world population and they have over $40 \%$ of the world GDP. Second, these two countries do not put the tax on one or two products and in fact, they are looking for bigger goals. More important the Donald Trump current president of the United States is a businessperson rather than a politician. The market size is the real matter of trade war (Miyagiwa et al., 2016) Americana and European have been always one side of the trade war in the world. According to the Office of the United States Trade Representative in 2017, the United 
States and China trade facts are so big. United States is the biggest market for Chinese with total estimated trade between China and United States \$710.4 billion were Chinese exported \$522.9 billion good a service to the United States and imported $\$ 187.5$ billion The U.S. goods and services trade deficit with China was $\$ 335.4$ billion in 2017 . China is still the biggest trading partner for the United States in \$635.4. The exported goods by the United States with \$129.9 billion and import totaled $\$ 505.5$ billion and the United States will huge goods trade deficit with $375.6 \%$. The trade in service with China is not as big as trade with goods (export-import) totaled about 75 billion. Where the Chinese are still the biggest exporter by $\$ 57.6$ billion and the service that they imported was about $\$ 17.4$ billion. The service trade surplus with China was about $\$ 40.2$ billion in 2017 the United States and China trade had created big job opportunities in the United States. According to the Department of Commerce, U.S. exports of Goods and Services to China supported an estimated 911,000 jobs in 2015 (601,000 supported by goods exports and 309,000 supported by services exports).

\section{Trade Balance}

- The U.S. goods trade deficit with China was $\$ 375.6$ billion in 2017 , an $8.2 \%$ increase (\$28.6 billion) over 2016 .

- The United States has a services trade surplus of an estimated $\$ 40.2$ billion with China in 2017, up 5.8\% from 2016(UTSR, 2018).

\section{Investment}

- U.S. foreign direct investment (FDI) in China (stock) was $\$ 107.6$ billion in 2017, a $10.6 \%$ increase from 2016. U.S. direct investment in China is led by manufacturing, wholesale trade, and finance and insurance.

- China's FDI in the United States (stock) was \$39.5 billion in 2017, down 2.3\% from 2016. China's direct investment in the U.S. is led by manufacturing, real estate, and depository institutions.

- Sales of services in China by majority U.S.-owned affiliates were $\$ 55.2$ billion in 2015 (latest data available), while sales of services in the United States by majority China-owned firms were $\$ 5.7$ billion (UTSR, 2018).

These big markets between the United States and China are big enough to influence other countries. ASEAN countries which are the most exposed countries to the United States and China trade war. Malaysia, Singapore, Thailand, Vietnam, Myanmar, Philippines, Laos, Cambodia, and Brunei do not have a big account to protect themselves. The trade between Malaysia and Indonesia influenced by the United States and China. The trade between Thailand and Malaysia also is influenced by the United States and China. The same situation is about the rest of the ASEAN countries. The situation is getting worse for the small and poor ASEAN states (UTSR, 2018).

Different institutes have different have the same analysis from the United States and China trade war impacts on ASEAN countries. The trade war between the United States and China has a negative impact on the world economy and risk global growth. According to the ASEAN Studies Centre at ISEAS-Yusof Ishak Institute is very pessimistic about 2019 is not very promising for Malaysia, Singapore, and Thailand. Also, the OECD estimated that if the potential trade war between China, United States, and European Union happens, it could lower the global growth by $1-1.5 \%$ and in medium term, it around $2 \%$ and increase the trade cost between the United States, 
European Union and China by 10\% (Andrews et al., 2018). The Peterson Institute estimation is very pessimistic about United States job opportunities. During a full trade war (proxied by a $45 \%$ tariff on non-oil imports from China and a 35\% tariff on non-oil imports from Mexico, with asymmetrical retaliation) would imply large job losses in the US ( 4.8 million jobs) but mostly concentrated in the non-trade service sector (Hufbauer and Jung 2018).

That said, the impact on ASEAN may vary due to different dependence on US-China trade and the potential recalibration of production lines and/or redirection of trade flows due to the tariffs. Singapore and Malaysia are potentially the most exposed, while Indonesia, Philippines and Vietnam may have less to lose based on our scorecard using the four criteria we chose (OCBC Bank, 2017).

The OCBC Bank in a scenario based report showed the situation for ASEAN countries will be very bad by the United States and China trade war. In fact, OCBC Bank provided two scenarios for potential impact on growth the two possible scenarios followed by (1) a mild trade war with US $\$ 50 \mathrm{~b}$ of US tariffs, and (2) a more severe trade war with US\$250b of US tariffs (OCBC Bank, 2017). These scenarios are based on how much the Chinese economy can tolerate and is capable to cope with them. In the first scenario, the trade war is mild with the US $\$ 50$ billion of the tariff, growth is very slow, and it is more inside China. In the second scenario with the US\$250b tariff, the risk will take over China and spills over to other countries. At the end of this research, the GDP growth estimated to range between $0.1 \%$ to $0.5 \%$ points. The ASEAN countries based on market size and population have a different degree of vulnerability to trade war. In this paper shows which ASEAN countries and with what degree of involvement is more vulnerable to the United States and China trade war.

The USTR Issues Tariffs on Chinese Products in Response to Unfair Trade Practices On May 29, 2018, announced that President Trump has included a long list of Chinese products that he triggered the industrial products those sectors that address the "made in China 2025". Which include industries such as aerospace, information and communications technology, robotics, industrial machinery, new materials, and automobiles. The United States listed 1012 separate United States tariff line. The report published in the 28710 Federal Register / Vol. 83, No. 119 / Wednesday, June 20, 2018, / Notices. This list of products contains two different kinds of products in the United States tariff lines. The first list contains 818 products out of 1333 lines that were included in the proposed-on April 6. These lines cover about $\$ 34$ billion worth of imports from China. USTR aimed to put up the additional duty of $25 \%$ on these 818 products after having sought and received views from the public and advice from the appropriate trade advisory. The second set contains 284 proposed tariff by the interagency Section 301 Committee as benefiting from the Chinese industrial policies, including the "Made in China 2025" industrial policy. These 284 lines will cover about $\$ 16$ billion worth of imports from China, which should have public notice. After that, there will look at the list again and see if certain products need to additional duties. USTR recognizes that some U.S. companies may have an interest in importing items from China that are covered by the additional duties. Accordingly, USTR will soon provide an opportunity for the public to request the exclusion of particular products from the additional duties subject to this action. USTR will issue a notice in the Federal Register with details regarding this process within the next few weeks (UTSR, 2018). 


\section{United States and ASEAN Business View}

United States and Association of Southeast Asian Nations (ASEAN) consist of Brunei Darussalam, Burma, Cambodia, Indonesia, Laos, Malaysia, Philippines, Singapore, Thailand, and Vietnam. The ASEAN countries are the fourth important business partners for the United States. The GDP in this big market is about \$2.4 trillion and 632 million population. Since 2010 the United States and ASEAN countries expanded very fast by $58 \%$, The main United States goods for export, including electrical machinery, machinery, aircraft, optical and medical instruments, and miscellaneous grain, seed, and fruit. United States domestic export of agriculture products $\$ 11.2$ billion. Service export to ASEAN countries in comparison to other sectors and in the short period from reaching to $\$ 27.1$ in 2015 . The service, product export from the United States to ASEAN countries had $11.7 \%$ growth in comparing to 2014. United States trade with ASEAN countries has created more than 500000 jobs just in the United States. In 2016 the two-way trade was up to \$ 234billion between the United States and ASEAN countries (UTSR, 2018).

United States in ASEAN countries looking for his own strategic goals rather than business. China influence in ASEAN countries has been always a big threat to the United States. As mentioned earlier the United States trade with ASEAN has in technology and industrial goods have increased since years ago. For the United States having and saving a market in ASEAN countries is for the sake of protecting their interests and control Russian and recently Chinese influence. The United States efforts in ASEAN countries show trade is very political and the ASEAN-U. S. Trade and Investment Framework Arrangement (TIFA) is just for cutting Chinese influence in the ASEAN region. After that ASEAN under the TIFA started Expanded Economic Engagement (E3) (United States Department of State 2013). The United States and ASEAN cooperation extended by ASEAN minister's endorsement of common approaches to investment in ASEAN-U.S. Cooperation in Fostering International Investment and transparency in the ASEAN-US Cooperation in Fostering Transparency and Good Regulatory Practices (USTR, 2018). The main reason for the United States cooperation, investment, and increasing the ASEAN standards, is to expand its influence to the lower layers in the ASEAN economy. As a prime example, work on specific standards development and practices; promoting opportunities for small- and mediumsized enterprises, and pursuing initiatives that advance United States common interests on trade and the environment. The corporation has not stopped at that level and it addressed cooperative activities that help the implementation of United States be easier and ASEAN countries have more participation in high-standard trade agreements, including through the U.S.-ASEAN Trade Workshops (United States Department of State 2013).

\section{China and ASEAN Business View}

The best business in two-way in ASEAN countries and after ASEAN countries themselves China is the second country with the most export and import. China as the biggest country in the world close to ASEAN countries owned $15.2 \%$ of total business, which imports $19.4 \%$ of products from China and $11.4 \%$ of total export to ASEAN countries. Whereas, the United States stands in the fifth level after the ASEAN, China, Japan, and European countries. The trade between the United States and ASEAN countries is totaled $9.4 \%$ of the total ASEAN countries with $7.6 \%$ import $10.9 \%$ export. It shows the United States looks for more influence in ASEAN countries by importing technology and industry and less on import. However, China looks for more energy and 
more agricultural products. China and United States efforts in ASEAN are about more physical and spatial expansion in these countries. They enter in the name of investment, banking, industrial development, and oil and gas, but the region it is important for them. In fact, there is a competition between China and the United States in ASEAN countries.

Table 1: ASEAN trade by partner countries/regions

\begin{tabular}{|c|c|c|c|c|c|c|c|}
\hline \multirow{2}{*}{$\begin{array}{l}\text { ISO } \\
\text { Code }\end{array}$} & \multirow{2}{*}{$\begin{array}{c}\text { Trade } \\
\text { partner } \\
\text { country }\end{array}$} & \multirow[b]{2}{*}{$\begin{array}{c}\text { Exports from } \\
\text { ASEAN }\end{array}$} & \multicolumn{2}{|c|}{ Value of trade (US\$million) } & \multicolumn{3}{|c|}{$\%$ Share to total } \\
\hline & & & $\begin{array}{l}\text { Imports by } \\
\text { ASEAN }\end{array}$ & Total trade & $\begin{array}{c}\text { Exports } \\
\text { from } \\
\text { ASEAN }\end{array}$ & $\begin{array}{c}\text { Imports } \\
\text { from } \\
\text { ASEAN }\end{array}$ & $\begin{array}{l}\text { Total } \\
\text { trade }\end{array}$ \\
\hline & ASEAN & $305,692.5$ & $238,058.7$ & $543,751.3$ & 25.9 & 21.9 & 24.0 \\
\hline \multirow[t]{2}{*}{$\mathbf{C N}$} & China & $134,249.4$ & $211,514.8$ & $345,764.2$ & 11.4 & 19.4 & 15.2 \\
\hline & Japan & $113,694.0$ & $124,350.4$ & $238,044.4$ & 9.6 & 11.4 & 10.5 \\
\hline $\mathbf{E U}$ & EU 28 & $127,583.8$ & $100,056.4$ & $227,640.2$ & 10.8 & 9.2 & 10.0 \\
\hline $\mathbf{U S}$ & $\begin{array}{l}\text { United } \\
\text { states }\end{array}$ & $129,170.5$ & $83,172.4$ & $212,343.0$ & 10.9 & 7.6 & 9.4 \\
\hline \multirow{3}{*}{$\begin{array}{l}\text { ISO } \\
\text { Code }\end{array}$} & \multirow{2}{*}{$\begin{array}{l}\text { Trade } \\
\text { partner } \\
\text { country }\end{array}$} & & \multicolumn{2}{|c|}{ Value of trade (US\$million) } & \multicolumn{3}{|c|}{ \% Share to total } \\
\hline & & $\begin{array}{c}\text { Exports from } \\
\text { ASEAN }\end{array}$ & $\begin{array}{l}\text { Imports by } \\
\text { ASEAN }\end{array}$ & Total trade & $\begin{array}{c}\text { Exports } \\
\text { from } \\
\text { ASEAN }\end{array}$ & $\begin{array}{c}\text { Imports } \\
\text { from } \\
\text { ASEAN }\end{array}$ & $\begin{array}{l}\text { Total } \\
\text { trade }\end{array}$ \\
\hline & ASEAN & $305,692.5$ & $238,058.7$ & $543,751.3$ & 25.9 & 21.9 & 24.0 \\
\hline \multirow[t]{2}{*}{$\mathbf{C N}$} & China & $134,249.4$ & $211,514.8$ & $345,764.2$ & 11.4 & 19.4 & 15.2 \\
\hline & Japan & $113,694.0$ & $124,350.4$ & $238,044.4$ & 9.6 & 11.4 & 10.5 \\
\hline $\mathbf{E U}$ & EU 28 & $127,583.8$ & $100,056.4$ & $227,640.2$ & 10.8 & 9.2 & 10.0 \\
\hline US & $\begin{array}{l}\text { United } \\
\text { states }\end{array}$ & $129,170.5$ & $83,172.4$ & $212,343.0$ & 10.9 & 7.6 & 9.4 \\
\hline
\end{tabular}

Source: ASEAN (2016)

There are many cases of conflicts between China and the United States in ASEAN countries. When a U.S. Navy P8-A surveillance aircraft recently flew near Fiery Cross Reef in the Spratly Islands in the South China Sea. This United States Navy action increased the risk of war. Therefore, the situation in ASEAN countries has bigger players (e.g. China-United States) European Union, Japan and Russia are the other players but not important in this research.

According to an assessment report by OCBC, the trade war between China and the United States can have a destructive impact on the ASEAN countries. The OCBC report is based on two bad scenarios. The first scenario is a mild trade war with \$50billion of US tariffs that will be tangible by China and Asian countries. The second scenario is under the serious trade war with $\$ 250$ billion of United States tariff and it will risk the China and Asian countries' GDP growth between $0.1 \%$ to $0.5 \%$ points.

Table 2 shows how significant is the China-United States Trade war the countries do not have a serious problem with scenario 1 . Scenario 2 and by imposing $\$ 250 \mathrm{~b}$ tariffs the growth scenario and the GDP growth cut in half and the ASIAN countries and in particular ASEAN countries. China, Malaysia, and Indonesia will have a serious problem with national development policies. 
Table 2: Scenario 1 and 2 forecasted for Singapore, China, South Korea, Hong Kong, Malaysia, and Indonesia

\begin{tabular}{|l|l|l|l|l|l|l|l|}
\hline Total trade growth (yoy) & SG & CN & JP & KR & HK & MA & ID \\
\hline Empirical 5M18 (January-May) & $5.7 \%$ & $16.6 \%$ & $11.6 \%$ & $10.9 \%$ & $10.1 \%$ & $17.1 \%$ & $16.9 \%$ \\
\hline No Tariff & $4.0 \%$ & $7.0 \%$ & $7.3 \%$ & $8.7 \%$ & $5.8 \%$ & $7.6 \%$ & $9.1 \%$ \\
\hline Scenario (1): US\$50b tariffs & $3.3 \%$ & $6.5 \%$ & $6.8 \%$ & $8.1 \%$ & $5.3 \%$ & $6.5 \%$ & $8.6 \%$ \\
\hline Scenario (2): US\$250b tariffs & $2.2 \%$ & $3.0 \%$ & $3.1 \%$ & $3.7 \%$ & $4.1 \%$ & $3.5 \%$ & $4.5 \%$ \\
\hline $\begin{array}{l}\text { Impact to GDP growth under } \\
\text { scenario (2) }\end{array}$ & - & $-0.5 \%$ & $-0.2 \%$ & $-0.3 \%$ & $-0.4 \%$ & $-0.3 \%$ & $-0.1 \%$ \\
\hline $\begin{array}{l}\text { Baseline GDP growth forecast } \\
\text { (no trade war) }\end{array}$ & $3.0 \%$ & $6.5 \%$ & $1.1 \%$ & $3.0 \%$ & $3.6 \%$ & $5.5 \%$ & $5.1 \%$ \\
\hline $\begin{array}{l}\text { Revised GDP growth under } \\
\text { scenario (2) }\end{array}$ & $2.7 \%$ & $6.0 \%$ & $0.9 \%$ & $2.7 \%$ & $3.2 \%$ & $5.2 \%$ & $5.0 \%$ \\
\hline
\end{tabular}

Source: CEIC, OCBC Bank (2018)

Table 3: Trade war scoreboard: Impact on ASEAN

\begin{tabular}{|l|l|l|l|l|l|}
\hline & $\begin{array}{l}\text { Document } \\
\text { manufacturing } \\
\text { sector }\end{array}$ & $\begin{array}{l}\text { Trade } \\
\text { exposure }\end{array}$ & $\begin{array}{l}\text { Integration in } \\
\text { global supply } \\
\text { chain }\end{array}$ & $\begin{array}{l}\text { Investment } \\
\text { Environment }\end{array}$ & Total \\
\hline Indonesia & 5 & 3 & 5 & 4 & 17 \\
\hline Malaysia & 6 & 6 & 7 & 4 & 23 \\
\hline Philippines & 5 & 4 & 5 & 2 & 16 \\
\hline Singapore & 5 & 7 & 7 & 4 & 23 \\
\hline Thailand & 7 & 6 & 6 & 2 & 21 \\
\hline Vietnam & 3 & 7 & 6 & 3 & 19 \\
\hline
\end{tabular}

Source: CEIC, OCBC Bank, WTO

*Countries include: SG, MA, ID, PH, TH \& VN based on Available data

Scores assigned range from 1-10 (the higher the score, the higher the potential impact that trade tensions could have on the country), based on 4 criteria:

1) The dominance of a country's manufacturing sector: calculated by manufacturing sector as a percentage of GDP.

2) A country's trade exposure: calculated by total trade as a percentage of GDP.

3) Integration in the global supply chain: Defined by the WTO as the sum of foreign valueadded content of a country's exports and value added supplied to other countries' exports.

4) Investment environment: Calculated by taking investments from US or China as a percentage of total FDI inflows.

The trade in the United States in two-way of export and import has different partners. Among the United States key trading partners China with $15.6 \%$ is the first, Japan $7.8 \%$, South Korea $6.5 \%$, Hong Kong 6.4\%, Germany 4.2\%, Australia 3.4\%, Vietnam 2.5\%, Netherlands 2.5\%, Malaysia $2.2 \%$, Mexico $2.1 \%$, Russia2.1\%, Brazil 2.1\%, India 2.1\%, Thailand 2.0\%, and the UK 1.9\% have the highest share in China trade. Furthermore, 7 countries out of 15 countries are Asian and Vietnam, Thailand, and Malaysia from ASEAN countries. 
On the other hand, among Chinese trade partners, the United States with $17.2 \%$ is the most important trade partner for China. After that, Canada 13.9\%, Mexico 13.5\%, Japan 5.5\%, Germany 4.4\%, South Korea 3.1\%, UK 3\%, France $2.1 \%$, India 1.9\%, Italy 1.7\%, Ireland $1.7 \%$, Netherlands $1.7 \%$, Switzerland 1.5\%, Brazil 1.5\%, and Singapore 1.5\%. China in Asia has 3 big trade partners out of 15 and among these three just Singapore has been in ASEAN countries.

The China business partners are more trans-regional and less with Asian and ASEAN countries in comparison to the United States that has very big trade partners in Asia and with ASEAN countries (OCBC, 2018). Importantly, China is the most important country that adds foreign values to ASEAN countries. China spatial economic expansion in the world made some benefits for East Asian and in particular ASEAN countries. China bilateral manufacturing and exports in ASEAN countries conducted a large amount of wealth and created the most complex global value chain between ASEAN countries United States, Korea, Germany and some important European Union countries. The regional integration in Asia and between ASEAN countries has made an effective impact on the global market. About $60 \%$ of final manufactured goods between 1995-2015 sent to trans-regional markets. However, the United States share in the world has been just $40 \%$ of the manufactured goods. Hence, ASEAN countries and China can increase their capacity and extend their market.

The impact of the United States and China war is significant for those countries which are more exposed to China and the United States economy, Countries with depended manufacturing sector to regional and global market, (OCBD, 2018) countries with sectoral development, countries that provide raw materials for China and United States, countries which their energy sector heavily relies on China and Russia, and Countries need foreign direct investment. Therefore, ASEAN countries with a different degree of exposure to the United States and China are Myanmar (28\%), Laos $(24.5 \%)$, Vietnam (22\%) and Indonesia (18.1\%) trade most heavily with China. Meanwhile, Vietnam (11.9\%), Malaysia (10.6\%) and the Philippines (10.2\%) are most exposed to the US.

\subsection{United States-China Trade War Impact on Singapore}

Asian countries accounted for over $70 \%$ of the trade in two ways in Singapore and at the same time, Singapore has a special place in the Asian economy. Figure 1 shows the level of Singapore export exposure by region and it shows that Singapore is too vulnerable to any issues among Asian, American, and European trade. Instead, the Singapore level of import exposure by region shows is countries that are more vulnerable to no Asian. Singapore import in comparing to export from European and American countries is much higher. While import from Asian countries in comparison to export shows a significant increase. Therefore, Singapore is too vulnerable to the United States and China war with the highest level of direct and indirect exposure. 


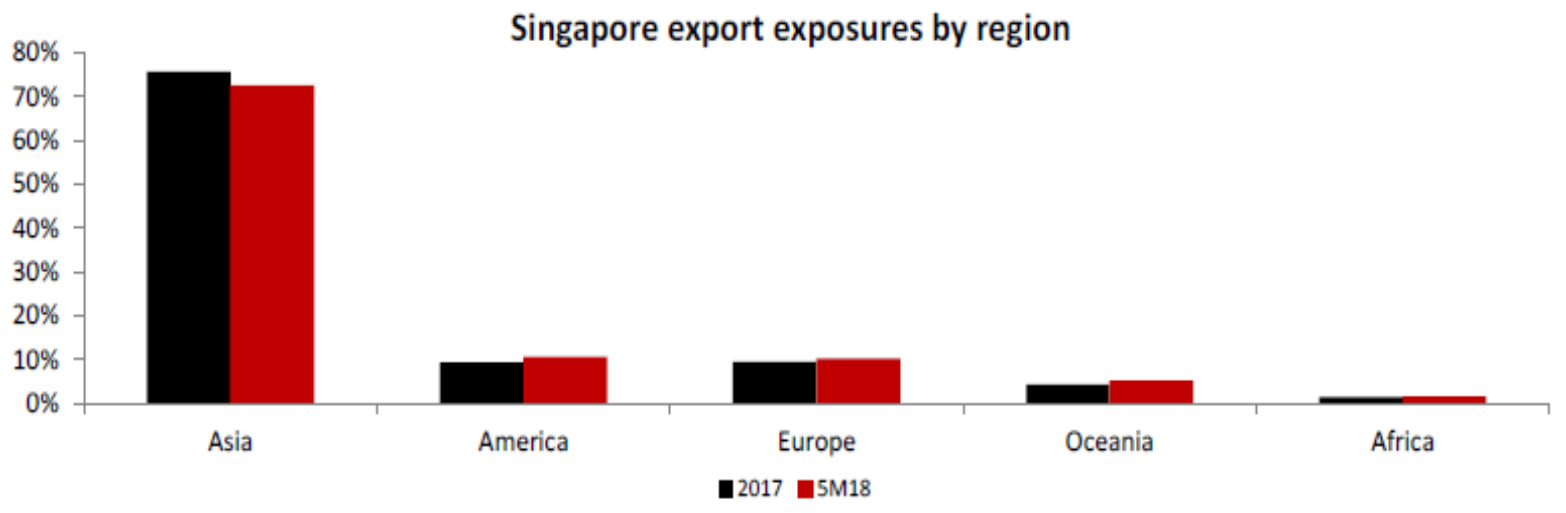

Figure 1: Singapore export exposure by region

Source: CEIC, OCBC Bank (2018)

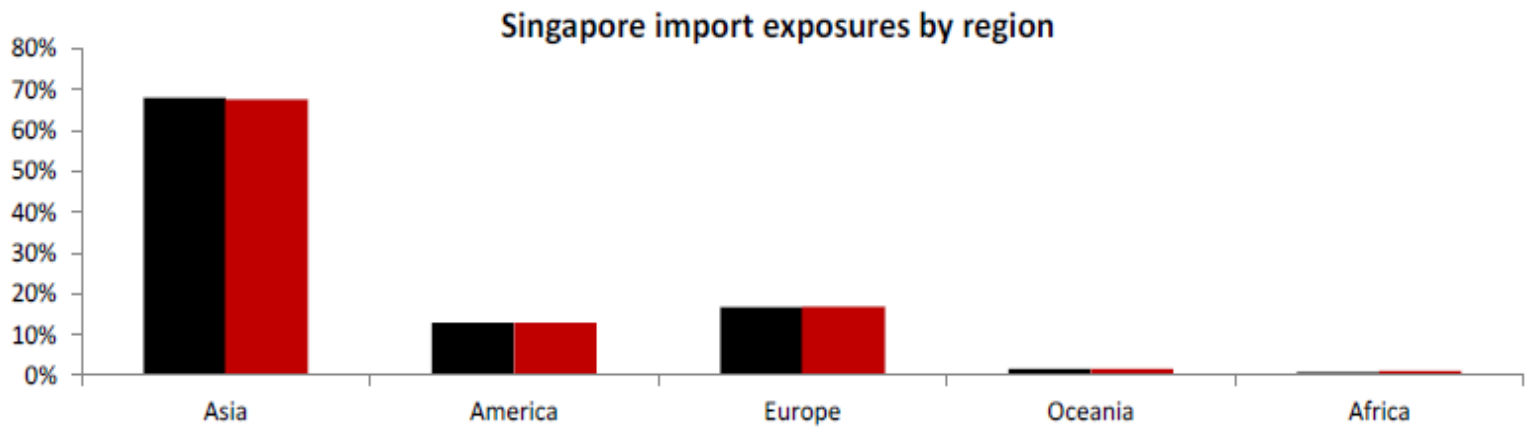

Figure2: Singapore import exposure by region

Source: CEIC, OCBC Bank (2018)

Direct and indirect United States and China trade war have increased the potential vulnerability in Singapore. Table 4 shows that Singapore totaled 20.8\% export and import with the United States and $24.3 \%$ export and import with China. Therefore, China has the biggest influence in the Singapore economy and the United States and China together have over 45\% influence in the Singapore economy. Important Singapore and China import and export are almost balanced with $14.5 \%$ export and $13.8 \%$ import whereas, Singapore trade with the United States with import $10.5 \%$ and $6.3 \%$ export is not balanced.

Table 4: Singapore export and import exposure to United States and China

\begin{tabular}{|lcc|}
\hline Exposure & China & United States \\
\hline Export & $14.5 \%$ & $6.3 \%$ \\
\hline Import & $13.8 \%$ & $10.5 \%$ \\
\hline
\end{tabular}

Source: CEIC, OCBC Bank (2018)

The potential vulnerable sectors to United States and China trade war are specific industries include:

1) Electronics, Chemicals

2) Maritime \& shipping industry. For non-manufacturing sectors such as finance, increased market volatility may drive capital flows and flight to quality

3) Banking and finance (OCBC, 2018). 
Figure 3 shows the role of different countries in Singapore Asia and trans-Asian trade. 10 country out of 15 important Singapore trade partners are Asian and 4 out of 10 are ASEAN countries which with $20 \%$ of total trade in Singapore are very important. Singapore is very exposed to the different direct and indirect impact of the United States and China trade war. First, Singapore has a big share in the United States and China economy which increases the direct negative impact of the United States and China trade war. Also, Asian countries will affect by the United States and China trade war will have an indirect negative impact in Singapore total business.

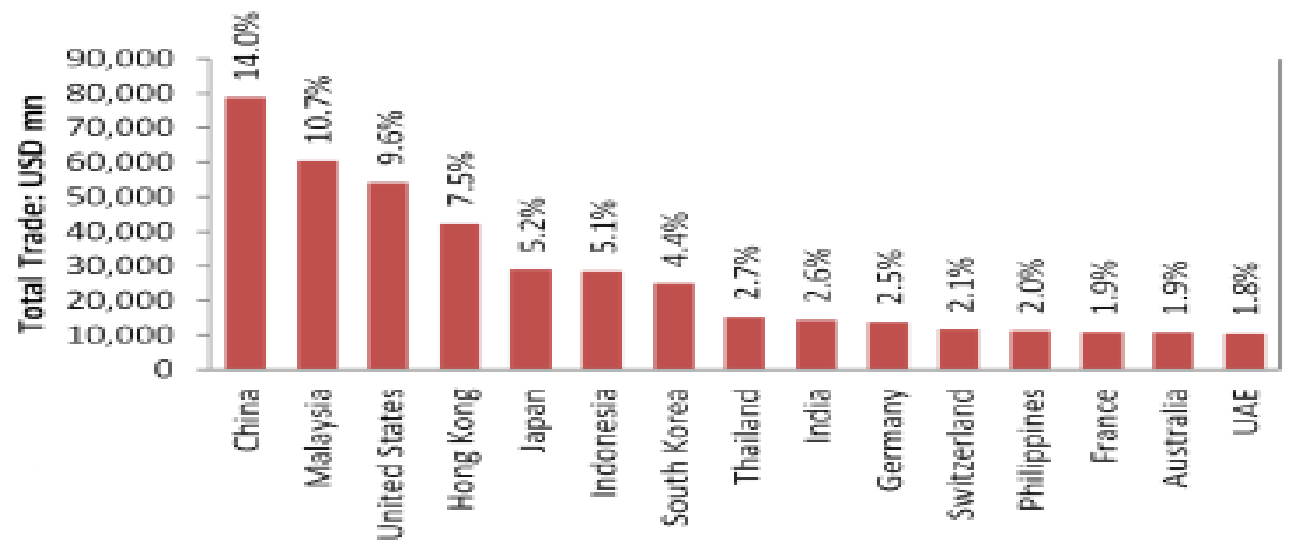

Source: CEIC, OCBC Bank (2018)

Figure3: Singapore total trade

The Unites States and China trade war has negative and positive points in different sectors in Singapore. There is a strong probability that the United States and China trade war increases the regional and inter-regional trade among Asian and ASEAN countries and shipping and logistics sector benefit from that. On the other hands, those industries that depend on United States investment, or technology (e.g., aluminum, manufacturing machinery, electronics) (OCBC, 2018) will loss. Singapore and entire ASEAN countries are not vulnerable to what they import from the United States or China. In fact, they are vulnerable from import and those sectors that rely on import from China and the United States.

\subsection{United States-China Trade War Impact on Malaysia}

The palm oil, solar panels, machinery, LED, and semiconductors will most probably affect the United States and China trade war. Different sectors in Malaysia will never get the same feedback from the trade war. Raw products in comparison to the industrial and manufacturing sector will improve (OCBC Bank 2018). Table 5 shows that China-Malaysia trade in terms of export and import is equal (18.4\% export and import 18.4\%) and higher than the United States (12.7\% export and $7.8 \%$ import).

Table 5: Malaysia export and import exposure to United States and China

\begin{tabular}{|lcc|}
\hline Exposure & China & United States \\
\hline Export & $18.4 \%$ & $12.7 \%$ \\
\hline Import & $18.4 \%$ & $7.8 \%$ \\
\hline
\end{tabular}

Source: CEIC, OCBC Bank (2018) 
After United States and China trade war, some sectors in Malaysia loss and some of them gain.

- Chemical products will "gain" because American replace Malaysian chemical products with Chinese products.

- Palm oil industry "gain" and will increase rapidly with United States tariff on soybean.

- LED industry "gain" Malaysia after China is the most LED supplier to United States and Malaysian can get the Chinese position.

- Solar Panel "loss" because of United States 30\% tariff and Malaysia provides 25\% of the total solar panel in Unites States.

- Machin part and components industries "loss" because some part of the Chinese products that export to China produce in Malaysia and tariff on them will get the negative impact of United States and China trade war.

- Electronics export to China "loss" Malaysia main trade with China are electronics and electrical products.

\subsection{United States-China Trade War Impact on Indonesia}

Raw agricultural and mineral products in Indonesia most probably affected by the United States and China trade war include machinery, coal, rubber, palm oil, iron \& steel. Table 6 shows that China has more influence in the Indonesian economy with $13.7 \%$ export and $22.8 \%$ import totaled $36.3 \%$ and the United States with $10.5 \%$ export and $5.25 \%$ import totaled $15.8 \%$. Where Chinese import is two times bigger than Chinese export, on the other hand, the United States is export two times bigger than the United States import.

Table 6: Indonesia export and import exposure to United States and China

\begin{tabular}{|lcc|}
\hline Exposure & China & United States \\
\hline Export & $13.7 \%$ & $10.5 \%$ \\
\hline Import & $\mathbf{2 2 . 8 \%}$ & $\mathbf{5 . 2 5 \%}$ \\
\hline
\end{tabular}

Source: CEIC, OCBC Bank (2018)

In fact, Indonesia has mixed influence from United States and China war.

- Indonesia does not have a significant place in the United States economy and there is not a very big business market between the two countries. However, the United States tariff on aluminium and steel will affect Indonesian industries, which rely on aluminium and steel.

- Metal base and articles from Indonesia to China are the third important export. United States tariff on Metal base might cause Chinese to prefer to dump other partners.

- Indonesia trade with China is very big and Indonesia base metal export to China is higher than the United States (OCBC, 2018).

\subsection{United States-China Trade War Impact on Vietnam}

United States and China trade war's impact on different sectors in Vietnam include clothing, footwear, garments, electronic parts, wood, and steel are different. China (16.5\% export and 27.5\% import) share in Vietnam market is two times bigger than the United States (19.3\% export and $4.4 \%$ import). Chinese import from Vietnam is bigger than Chinese export. On the other hand, United State export is 4 times bigger than United States import. 
Table 7: Vietnam export and import exposure to United States and China

\begin{tabular}{|lcc|}
\hline Exposure & China & United States \\
\hline Export & $16.5 \%$ & $19.3 \%$ \\
\hline Import & $27.5 \%$ & $4.4 \%$ \\
\hline
\end{tabular}

Source: CEIC, OCBC Bank (2018)

- Textile and garments might "gain" from high demand and shifting from China neighbouring countries.

- Consumer and goods industry "gain "China has (China plus one) strategy and Vietnam is part of that strategy for the low cost of living and cheap labour force.

- Machine parts "loss" Vietnam in this sector is intermediate and they support the Chinese market that export to the United States.

- Steel "loss" will affect by tariff as the 12th steel exporter

- Manufacturing "mixed" Vietnam as neighbouring country can get benefits. However, there is a big fear of dumping Chinese products.

\subsection{United States-China Trade War Impact on Philippines}

Philippines, among other ASEAN countries have a different situation in the United States and China trade war. The Philippines national planning policy at the local level is not intertwisted to regional and global facts. Therefore, despite Philippines trade exposure to the United States and China trade war country development relies on domestic consumption and the Philippines do not feel the impact. However, their impact trade war will be on steel, pork, electronics, processing.

Table 8 shows that China has a bigger influence than the United States in the Philippines. The Chinese share in Philippines export with 10.4\%, slightly lower than Americans does with $13.4 \%$. Whereas, the Chinese import with 17.6\% from the Philippines is by the far bigger than the American import with $7.8 \%$. China and the United States together have about $49.2 \%$ of Philippines export and import.

Table 8: Philippines export and import exposure to United States and China

\begin{tabular}{|lcc|}
\hline Exposure & China & United States \\
\hline Export & $\mathbf{1 0 . 4 \%}$ & $\mathbf{1 3 . 4 \%}$ \\
\hline Import & $\mathbf{1 7 . 6 \%}$ & $\mathbf{7 . 8 \%}$ \\
\hline
\end{tabular}

Source: CEIC, OCBC Bank (2018)

- Pork "gain" from the United States tariff on Chinese pork and Philippines pork can take over the Chinese market.

- Steel "gain" as the Philippines is one of the steel importers from the United States and they might lose their clients due to the tariff on steel.

- Electronics "loss" as the United States and China are a big export destination and import origin for electronic products in the Philippines

- Finance "loss" in fact, is not just about what protectionists think about export and import it might address FDI.

- United States-China trade war impact on Thailand 
Thailand automotive industry and fresh processed fruits will affect by China and United States trade war. The trade conflict between will harms the tiny primary Thailand export. However, Thailand shifted from China to United States and the trade between Thailand and United States passed 20 billion in 2017.

Table 9 shows Chinese influence in Thailand trade is 2 times bigger than American. Chinese export with $12.5 \%$ and American with $11.2 \%$ shows slightly different. However, Chinese import with $20 \%$ is 3 times more than the American import by $6.7 \%$.

Table 9: Thailand export and import exposure to United States and China

\begin{tabular}{|llc|}
\hline Exposure & China & United States \\
\hline Export & $12.5 \%$ & $11.2 \%$ \\
\hline Import & $20 \%$ & $6.7 \%$ \\
\hline
\end{tabular}

Source: CEIC, OCBC Bank (2018).

- Fresh and processed fruit "gain" Thailand after Chinese tariff on American agricultural products can open special place in never ended Chinese fruit and agriculture market.

- Automotive "gain" as Thailand is one of the most important players in ASEAN countries after American tariff on the car and spare part. Thailand attracts European companies to the Thailand manufacturing plant.

- Tech products "loss" intermediate Chinese goods that assembles in Thailand.

\subsection{United States-China Trade War Impact on Myanmar}

Entire industries in Myanmar are vulnerable to the trade conflict, including cattle, FDI, fish, natural gas and wood. Table 10 shows the Chinese influence in Myanmar economy is 12 times bigger than Americans. Chinese export with $29.9 \%$ is 17 times bigger than American export with $1.7 \%$. In addition, Chinese import with $26.6 \%$ is 8 times higher than American import with $3.4 \%$. Chinese and American together totaled $61.6 \%$ of Myanmar trade. Chinese influence in Myanmar economy is very deep and from $61.6 \%$ of Myanmar economy is very deep and from $61.6 \%$ of Myanmar export and import 56.6\% are Chinese share and 5.1\% is American shared.

Table 10: Myanmar export and import exposure to United States and China

\begin{tabular}{|lcc|}
\hline Exposure & China & United States \\
\hline Export & $\mathbf{2 9 . 9 \%}$ & $\mathbf{1 . 7 \%}$ \\
\hline Import & $\mathbf{2 6 . 6 \%}$ & $\mathbf{3 . 4 \%}$ \\
\hline
\end{tabular}

Source: CEIC, OCBC Bank (2018)

Myanmar with huge Chinese influence in both cattle and manufacturing gain.

- Cattle "gain" United States tariff on Chinese agricultural products gives a good opportunity to Myanmar in beef market. Hence, Chinese signed an agreement with Myanmar to increase cattle export to China.

- Manufacturing "gain" there is an interest between Chinese firms to open the factory and business in Myanmar. The Thilwa Special Economic Zone is the most interested place for Chinese to invest. 


\subsection{United States-China Trade War Impact on Cambodia}

Cambodia has a big trade with the United States, which is textile is dominated as the biggest and most important. Therefore, the trade war between the United States and China does not have a significant impact in Cambodia.

Table 11 shows the Chinese export to Cambodia with $12.5 \%$ is slightly higher than American export by $11.2 \%$. Instead, Chinese import with $20 \%$ is 3 times higher than American import with 6.7\%. Furthermore, Chinese with $32.5 \%$ and American with $17.9 \%$ totaled $50.4 \%$ trade in Cambodia.

Table 11: Cambodia export and import exposure to United States and China

\begin{tabular}{|llc|}
\hline Exposure & China & United States \\
\hline Export & $12.5 \%$ & $11.2 \%$ \\
\hline Import & $20 \%$ & $6.7 \%$ \\
\hline
\end{tabular}

Source: CEIC, OCBC Bank (2018)

\subsection{United States-China Trade War Impact on Brunei}

Brunei has less trade exposure to China and the United States and that is not significant. China with $2.2 \%$ and the United States with $0.4 \%$ have a minimum impact on the Brunei economy. However, Chinese import with $20.8 \%$ from Brunei is two times bigger than the American with 9.4\%. Chinese and American influence in Brunei export and import is less than entire ASEAN countries with $23 \%$ Chinese and $9.8 \%$ American and they totaled $33.1 \%$ which Chinese trade with Brunei is 2 times higher than American.

Table 12: Brunei export and import exposure to United States and China

\begin{tabular}{|llc|}
\hline Exposure & China & United States \\
\hline Export & $2.2 \%$ & $0.4 \%$ \\
\hline Import & $20.8 \%$ & $9.4 \%$ \\
\hline
\end{tabular}

Source: CEIC, OCBC Bank (2018)

\subsection{United States-China Trade War Impact on Laos}

Chinese are the biggest exporter in the Laos market and Laos export machinery in the United States. The trade conflict does not have a significant impact on Laos economy. However, the United States and China trade war can give better opportunity that after tariff of Chinese machinery products loss products take over part of the American market.

Table 13 shows that Chinese with $28.6 \%$ export Laos 15 times higher than American with $1.8 \%$. and Chinese import from Laos with $21.5 \%$ is 43 times higher than American with $0.4 \%$. However, the United States $2.2 \%$ and Chinese with $50.1 \%$ totaled $52.3 \%$ of Laos. 
Table 13: Laos export and import exposure to United States and China

\begin{tabular}{|lcc|}
\hline Exposure & China & United States \\
\hline Export & $\mathbf{2 8 . 6 \%}$ & $\mathbf{1 . 8 \%}$ \\
\hline Import & $\mathbf{2 1 . 5 \%}$ & $\mathbf{0 . 4 \%}$ \\
\hline
\end{tabular}

Source: CEIC, OCBC Bank (2018)

\section{Conclusions and Recommendations}

American and Chinese owned the biggest parts of trade in ASEAN countries, which is usually over 50\%. However, Chinese has the biggest influence and share among ASEAN countries. Chinese and American do not have the same interests in these countries. By the better words, where Chinese export to a country is bigger, the American export is lower and when Chinese import is lower American import is higher.

The ASEAN countries are very important for China because they are big market and close to China, energy and natural resources, food and agricultural products. American look for the same thing and they want to keep their hegemony in Asia and Among ASEAN countries in competition with Russia and China.

Chinese has a very deep influence in poor ASEAN countries including Myanmar, Cambodia, Brunei, and Laos. Chinese share from import and export in poor ASEAN countries sometimes is over 50\%. The countries with the highest level of exposure to China and the United States trade will be more vulnerable to the future consequences. However,

Finally, the first United States tariff does not have significant impact on ASEAN countries. The second United States tariff on Chinese products will affect different sectors in ASEAN countries. The statistics show those countries that have less level of exposure to the United States and China are in safer situation. Therefore, it is very important for ASEAN to have more regional integration for future impacts of trade conflicts in the world. Also, they should look for new markets and reduce their dependency to United States and China.

\section{References}

[1] World Bank, 2019, World Development Indicators database, World Bank, 25 January 2019 1. GDP data source: http://data.worldbank.org/data-catalog/world-development-indicators.

[2] Miyagiwa, Kaz, Huasheng Song, and Hylke Vandenbussche. "Size matters! Who is bashing whom in trade war?." International Review of Economics \& Finance 45 (2016): 33-45.

[3] Mun, S.T. Thuzar, M. Ha, T.H. Chalermpalanupap, T. Thao, Ph, T. P. Qian, S.A. 2019. The State of South East Asia. The "State of Southeast Asia: 2019" survey was conducted by the ASEAN Studies Centre at ISEAS - Yusof Ishak Institute between 18 November and 5 December 2018. The survey assessed the views of over 1,000 Southeast Asians on the region's strategic and economic situation in 2019, as well as views on major power engagement in the region

[4] Hufbauer and Jung 2018. No Winners in a US-China Trade War. https://piie.com/ commentary/ op-eds/no-winners-us-china-trade-war

[5] Andrews, D. Gal, P. and Witheridge, W. OECD. 2018. A genie in a bottle? globalisation, competition and inflation. ECONOMICS DEPARTMENT WORKING PAPERS No. 1462

[6] OCBC Bank. 2018. Trade tariffs \& its impact on ASEAN. Treasury Research \& Strategy. CEIC, OCBC Bank *Top exports to $\mathrm{CN}$ in 2017 unavailable. 
[7] UTSR, 2018. USTR Issues Tariffs on Chinese Products in Response to Unfair Trade Practices.https://ustr.gov/about-us/policy-offices/press-office/press-releases/2018/june/ustrissues-tariffs-chinese-products

[8] The U.S-ASEAN Expanded Economic Engagement (E3) Initiative. 2013. Fact Sheet. Office of the Spokesperson. Washington, DC. October 9, 2013

*Corresponding author.

E-mail address: space.kamran@gmail.com 